\title{
Armenia: Transformational Peculiarities of the Soviet and Post-Soviet Higher Education System
}

\author{
Susanna Karakbanyan
}

\section{INTRODUCTION}

Schools of higher learning were initiated in Armenia as early as the ninth century and one of the first schools was Tatev Academy. From the thirteenth through the fifteenth century, the fame of some schools spread beyond the borders of the country. This included the University of Gladzor, which celebrated its 700th anniversary in 1980 under the aegis of UNESCO (2000). Historically, schools of higher learning were located in churches. Strict management rules were applied as early as the thirteenth century to ensure adequate qualifications for teachers and admission of the best students. In medieval Armenia, schools of higher learning had already begun conferring the scientific degrees of "Archimandrite" and "Rabbi" upon successful completion of oral and written examinations, and thesis defence (ibid).

Armenian schools of higher learning saw a major expansion between the eighteenth and nineteenth century to various worldwide locations

S. Karakhanyan $(\bowtie)$

ANQA Accreditation Commission, Yerevan, Armenia

(C) The Author(s) 2018

J. Huisman et al. (eds.), 25 Years of Transformations of Higher

Education Systems in Post-Soviet Countries, Palgrave Studies in Global

Higher Education, https://doi.org/10.1007/978-3-319-52980-6_3 
such as Venice (Mkhitarian College), India (Calcutta College), Moscow (Lazarian Seminary), Tiflis (Nersisian School), Echmiadzin (Gevorkian Seminary), Madras and Rostov (ibid).

In 1920, schools were separated from the church and the whole system of education became state-owned. As elsewhere in the Soviet republics, primary, secondary and tertiary education was free, and tertiary education was elite in both social and intellectual dimensions. Considering that education has always been a central value of Armenian culture, the country enjoyed a $100 \%$ literacy rate as early as 1960 (Suny 1996, 36).

With the fall of the Soviet Union (SU) in 1991 and the sudden cessation of Soviet standards and rules, the first years of Armenia's independence were marked by a vacuum in education and culture. The abrupt absence of a dominating power created social and political confusion, thus filling the vacuum with the standards of a new and more powerful country (Terzian 2010) mainly influenced by educational policies from Anglophone and Anglo-centric systems. In the early 1990s, Armenia made substantial changes to a centralised and regimented system that evolved with advantages and disadvantages.

The aim of this chapter is to explore the HE landscape in Armenia before and after the fall of the Soviet regime and the respective transformations reflected by social needs, economic demands and political goals. In particular, we will look at the Soviet model of institutional diversity in Armenia, followed by the main drivers of transformation after the fall of the Soviet regime and the factors that stimulated or impeded institutional differentiation (van Vught 2007). The chapter will culminate in a presentation of the current institutional landscape and the contextual factors affecting it.

\section{The Soviet Model of Institutional Diversity}

\section{IN ARMENIA}

Armenia became part of the SU in December 1923. Consequently, at the start of the twentieth century, the whole concept and ideology of education radically changed to become permeated with one idea: the collective self, which became more important than the individual self (Sarafian 1930). By becoming part of the SU, the higher education (HE) system in Armenia witnessed a cessation of the ecclesiastical era and the beginning of horizontal differentiation with the emergence of professionally oriented schools, new professionally oriented institutes, universities and art schools to serve societal needs (Sarafian 1930). The only 
university from the Soviet era in Armenia, the National University of Armenia, was renamed Yerevan State University (YSU) in 1922. It was founded in 1919 by Ministerial decree and was established based on a rich history of higher learning preserved by the church; it "renewed the ancient traditions of Armenian scholarship in language and history that during 600 years of foreign occupation had flourished only among the diaspora abroad" (NAS 2004, 11).

From the 1920s to the fall of the Soviet regime, the system evolved in line with Communist Party (CP) directives, socialist and communist ideology and the demands of the industrialisation agenda. Higher education institutions (HEIs) in that period were purely public and free of charge. As early as at the beginning of the 1920s in tandem with the Cultural Revolution reforms that swept the USSR, technical and agricultural schools as well as workers' universities gradually evolved into new professionally oriented institutes (e.g. in 1922 Armenian State Pedagogic Institute and in 1933 Yerevan Polytechnic Institute).

In 1930, in accordance with the government and on the basis of YSU faculties, independent professionally oriented institutes were established. Among these were the State Medical Institute, the Armenian Construction Institute, and the Yerevan Agriculture Institute. In the 1970s, a major boom in HE enrolment was recorded (Fig. 3.1). This could be partly explained by industrialisation policy requiring more educated employees and partly by the full transition from seven-year education to ten-year secondary education as well as massive provision for compulsory secondary education (with consideration of vocational education) for all citizens (Chabe 1971).

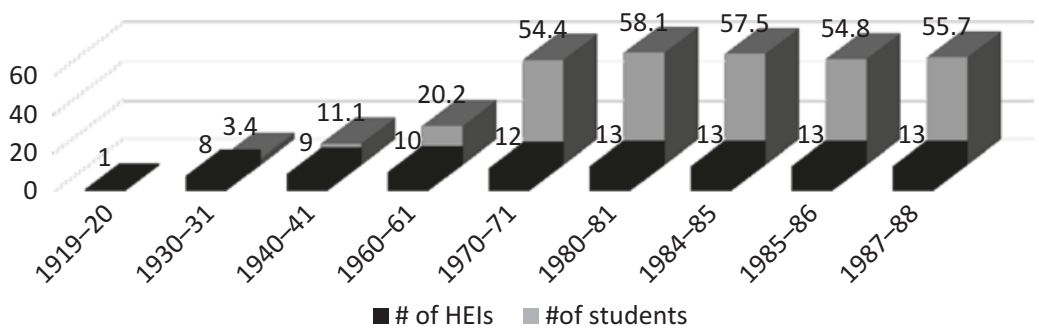

Fig. 3.1 Number of HEIs with total enrolment figures (in thousands) at the start of selected academic years (Data collected from different sources: UNESCO, HE in the USSR, Monographs on HE edited by L. C. Barrows; Khudaverdyan, K. S, 1960) 
Based on a strictly centralised model, the HE system was uniform. In 1988 just before the fall of the Soviet regime, there were 13 HEIs in Soviet Armenia, of which only YSU was qualified as a full university. The others were 11 professionally oriented institutes and 1 conservatorium. The schools of higher learning had a combined student body of 55,700 specialising in 103 professions leading to a 5 -year diploma specialist qualification (Table 3.1).

During the Soviet regime, Armenia had one of the highest percentages of HE attendees per capita in comparison to other USSR republics, and science was a particularly popular field of study (NAS 2004). One major development during Soviet times that drastically affected HEI research capacity was the removal of research from HEIs. It was placed under the Armenian Branch of the Academy of Sciences of the USSR in 1935. As a result of this separation, the boundaries between professional and research HEIs gradually blurred, as the only distinction between the HEIs was whether they comprehensively covered a variety of study fields or only one

Table 3.1 Higher education landscape in Armenia in 1991

\begin{tabular}{|c|c|c|c|}
\hline Type of HEIs & $\begin{array}{l}\text { Number } \\
\text { of HEIs }\end{array}$ & Specific example & Description \\
\hline Full university & 1 & $\begin{array}{l}\text { Yerevan State } \\
\text { University }\end{array}$ & $\begin{array}{l}\text { Higher, postgraduate and } \\
\text { supplementary education in } a \\
\text { wide variety of natural and } \\
\text { sociological fields, science, } \\
\text { technology and culture, as } \\
\text { well as providing } \\
\text { opportunities for scientific } \\
\text { research and studies }\end{array}$ \\
\hline $\begin{array}{l}\text { Professionally } \\
\text { oriented institute }\end{array}$ & 11 & $\begin{array}{l}\text { Yerevan Polytechnic } \\
\text { Institute }\end{array}$ & $\begin{array}{l}\text { HEI conducting specialised } \\
\text { and postgraduate academic } \\
\text { programmes and applied } \\
\text { research in a number of } \\
\text { field-related scientific, } \\
\text { economic and cultural } \\
\text { branches }\end{array}$ \\
\hline Conservatorium & 1 & $\begin{array}{l}\text { Yerevan Komitas State } \\
\text { Conservatorium }\end{array}$ & $\begin{array}{l}\text { HEI preparing specialists in } \\
\text { the field of music, providing } \\
\text { qualifications, development } \\
\text { and postgraduate academic } \\
\text { programmes }\end{array}$ \\
\hline
\end{tabular}


single field. Although the separation strictly served the Soviet agenda of supporting military-industrial complexes, it also resulted in the establishment of a rich tradition in research activities, particularly in physics, and ensured strong government support to promote education in science and engineering in Armenia. The Academy of Sciences became a centre of science and technology research providing support services to the entire SU (NAS 2004). Just before the fall of the regime, there were about 36 research institutions within and outside the Academy. In 1940, 11 of the 36 belonged to the Armenian Branch of the Academy of Sciences of the USSR and directly reported to either federal agencies in Moscow or to local Armenian ministries (Khudaverdyan 1960) (NAS 2004).

All the HEIs were under the auspices of the Ministry of Education and Science (MoES), with respective line ministries for the Medical Institute and the Agriculture Institute. They were state funded and followed the model of curriculum and teaching methods imposed from Moscow. The HE system was unitary with no differentiation between professional and academic programmes/qualifications and a strong bias towards the provision of practical knowledge directly linked with industry (Sarafian 1930).

Further, HE system uniformity was spelled out in a centralised and unified approach to HEI governance, since the only directives eligible for implementation came from a higher level, the Central CP in Moscow, and were imposed on HEIs without any right to deviate. In fact, the CP considered education too important to delegate to education professionals, and it was thus the political leaders who designed education policies and steered the respective developments (Chabe 1971). One of the negative impacts of such a centralised approach was a decrease in system capacity to develop and innovate. The isolated system gradually turned the HE leaders in Armenia and other Soviet republics into mere implementers with no opportunities to reflect on the imperatives coming from Moscow or question approaches related to content and methodology.

Although paralysed in the sphere of social sciences, the technical and natural sciences proliferated in Armenia. Just before the fall of the SU, Armenia enjoyed a strong body of professionals advancing research in the fields of hydro-energy, nuclear energy, radio-electronics, machinery production, precise machine-making, laser technology, biochemistry, microbiology, and light and heavy textile industry. The number of persons per 10,000 enrolled in Armenian HE was 161, compared to the overall average of 177 for the USSR (UNESCO 1990). From every thousand employed people, 192 and 222 had a higher and secondary professional education, respectively (UNESCO 2000). 


\section{Post-Soviet Transformations}

After the dissolution of the SU, Armenia faced challenges related to resurrection of its identity and recovery of its economic, cultural and educational values. The country was in major need of transformation at different levels to ensure its survival and later competitiveness at the international level. The economic crisis and political tensions were priority issues to be dealt with, as they were caused by the radical change in the political system.

Firstly, the country experienced a drastic earthquake in 1988 followed by political tension with neighbouring Azerbaijan over a historically Armenian territory, Mountainous Karabagh. This geared the major investments of the Armenian government from development towards a vision of preserving the national identity and resurrecting rich historical and cultural legacy. Two major trends related to political tension evolved, which eventually had a major impact on the socio-economic development of the country. One was an inflow of refugees from Azerbaijan, and the other was the "brain drain" of Armenian human capacity to countries offering more opportunities for growth. According to CARIM, major social changes resulted from hosting refugees from Azerbaijan and other Soviet republics; there were over 420,000 between 1988 and 1991, with 360,000 from Azerbaijan alone (UNHCR 2004; CARIM 2013). The trend is still persistent with a refugee inflow from Syria. Further, a major outflow of both citizens and refugees has been registered. The 2004 UNHCR Statistical Yearbook estimates the number of outflowing people from Armenia to developed countries to be above 13,000. According to the State Migration Authority data as of 2013, about 42,800 people left the country in 2012 without returning. Thus, the two trends have contributed immensely to the existing lag in economic development and consequently reflected in government investment into HE.

While popular during Soviet times, Armenian industry has now declined and the country has experienced a major blow to the economy. Caused by political tension, war and blockades, most industries were closed, which led to rising unemployment and economic paralysis. In addition to economic, political and social issues, the system had to deal with the legacy of several decades of a communist regime that was deeply rooted in all aspects of life and therefore the culture, beliefs and values of Armenia (Kozma and Polonyi 2004) (Zelvys 2004). Formed throughout the 70 years of the Soviet regime, exceptionally peculiar culture and values made the transformations to the market economy and democracy complicated, leading to 
distortions in many cases. These factors included Soviet trust vs. Western responsibility, nihilism and negotiation vs. competition, humanity vs. professionalism, truth vs. rules, faith vs. stimulus, "universalism" vs. individualism, spirituality vs. interests and charity vs. justice (Khrushcheva and Benvenuti 2002).

In the 2000s, Armenia demonstrated steady economic growth until the global crisis hit the economy. According to the Index of Economic Freedom 2009, Armenia was ranked the 39th most economically free nation in the world, and as of 2012 it had made a full transfer to the market economy (MoES 2014). In 2009, the real GDP rate declined by $14.1 \%$, followed by a slow recovery, registering a GDP growth of $2.2 \%$ in 2010 and $4.7 \%$ in 2011 .

So, what were the changes in the $\mathrm{HE}$ arena based on these trends? In tandem with the changes in the political system, changes took place in HE. After the fall of the communist regime, the liberalisation of the country and a move towards a market-driven economy was the apparent trend. The first step was related to the resurrection of the Armenian identity and was registered with curricula emphasising Armenian language, history and culture. The Armenian language became the dominant language of instruction followed by English, although Russian was still widely taught as a foreign language. Because of the political tension, few and fragmented changes were possible in HE in the early 1990s.

As seen from the figure below, the enrolment of students in the HE sector remained unchanged up to 1999. Starting with the 1999-2000 academic year, a move from "elite" $\mathrm{HE}$ to mass education became apparent. This trend was also conditioned by the appearance of private sector providers enforced by the Law on Education adopted in 1999. The same cannot be said about vocational education providers (so-called technicums or professional colleges/uchilishe). This sector has remained relatively constant since Soviet times (Fig. 3.2).

Massification of $\mathrm{HE}$ is explained by several factors: the demand for a more qualified workforce in the market, the growing prestige of $\mathrm{HE}$ enrolment over Vocational Education and Training (VET) and the country's strategic priority of establishing a knowledge economy.

As can be seen from Fig. 3.3, among the most preferred programmes offered by HEIs predominance is in humanities, education and pedagogy, economics and management, the agro/food sphere, public health and culture and arts. To a lesser extent, programmes in physical-mathematical and natural sciences are also registered as preferred. There has been a steady 


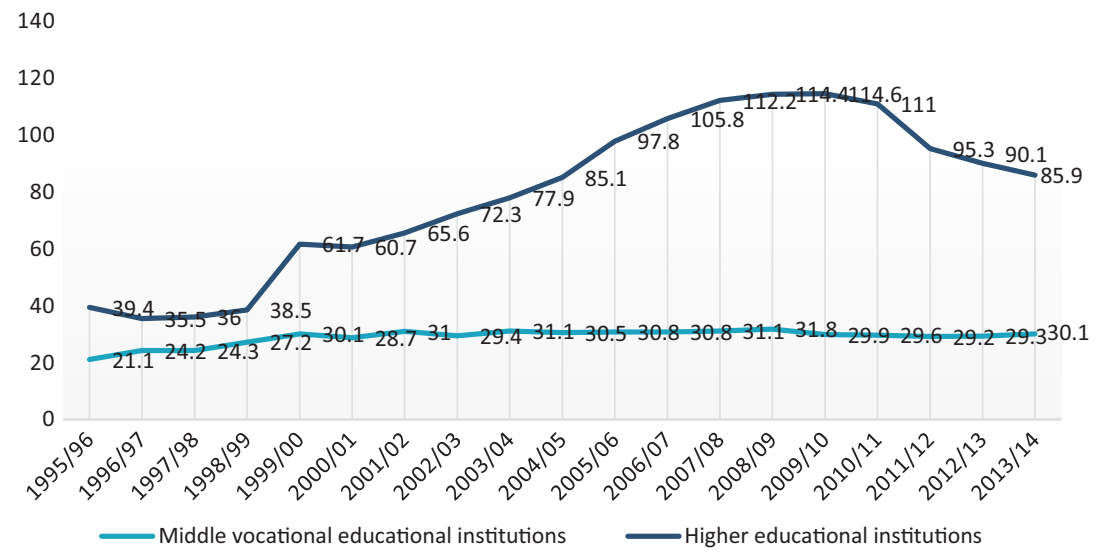

Fig. 3.2 Enrolment in tertiary education institutions in Armenia (Statistical Yearbook of Armenia: http://www.armstat.am/en/?nid=45\&year=2014)

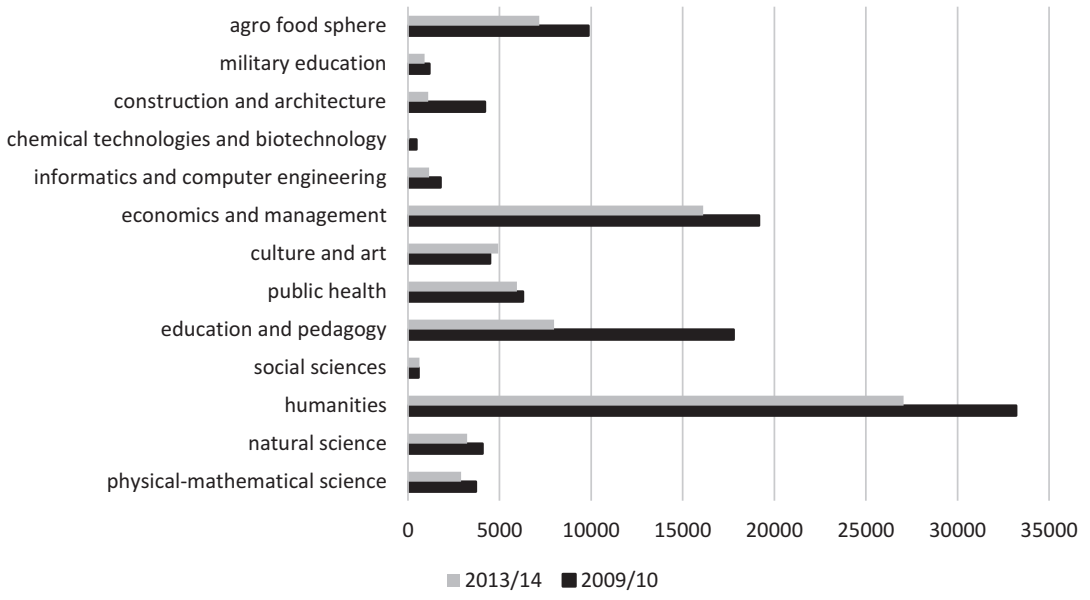

Fig. 3.3 Student enrolment per major (BA level) (Statistical Yearbook of Armenia): http://www.armstat.am/en/?nid=45\&year=2014)

rise in information technologies throughout the last 6 years, which is a good sign of demand on the HE system by the labour market.

One of the consequences of the granted freedom in HE provisions is the overabundance of professionals in management and economics, law, 
humanities and some spheres of engineering. This adds to unemployment to a major extent, taking it from $3.8 \%$ in 2008 to $18.7 \%$ in 2009 and beyond (NSSRA 2014).

According to the Statistical Yearbook of Armenia (2014), only $62.8 \%$ of HE graduates were actually employed in 2013.

Further in terms of employment, the official demand from the labour force (for wage earners) as submitted by employers is steadily growing, while there are fewer and fewer applicants per vacant position. A high degree of unemployment is apparent and it has marred the economy of the country for two major reasons. Firstly, HEIs have continued offering traditional study programmes based on the academic standards stipulated by the government without harmonising the offered qualifications with market needs. Secondly, the market itself was and still is in the process of formation with high reliance on the personal capacities of the workforce to manage environmental and organisational changes, rather than on the education and qualifications received (Fig. 3.4).

The period after 1998 can be characterised as a recovery period for the country in all the dimensions: economic, political and cultural. One sign was a steady increase in public spending on education until the late 2000 s when the next economic crisis hit in 2009. The education sector suffered with a drastic cut of about $15 \%$ from the original budget with no indication of recovery (WB 2013). Overall, according to the WB Public Expenditure Review (WB 2011), public funding for tertiary education was well below the regional average of $1.3 \%$ and the OECD average of $2.0 \%$, taking it down to $0.3 \%$ of GDP and $10-12 \%$ of total education spending,

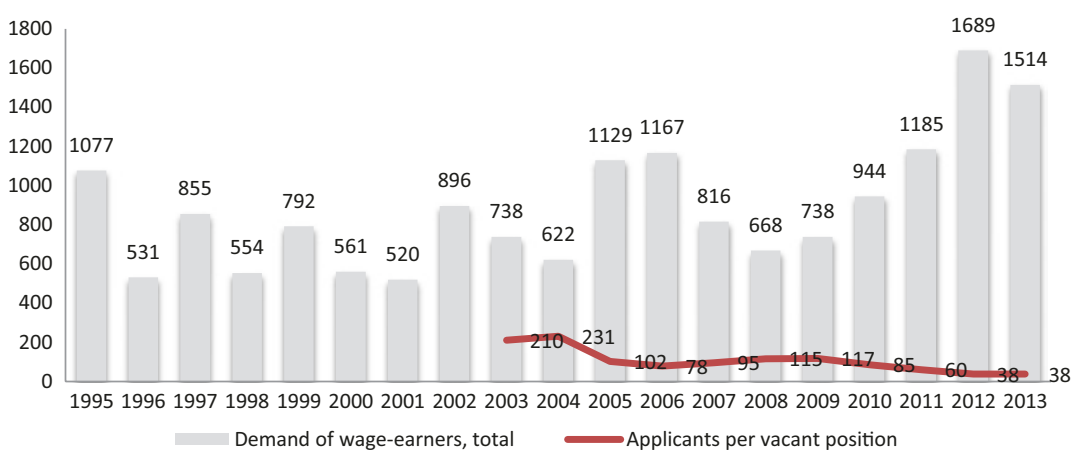

Fig. 3.4 Official labour force demand submitted by employers (Statistical Yearbook of Armenia: http://www.armstat.am/en/?nid=45\&year=2014) 
respectively. Public funding for research and development (R\&D) is as low as $0.2 \%$ of GDP and the priority allocation is for the NAS, which doubly limits HEI research capacity. The 2010-2013 state budget allocated for education and science underwent a steady decline, taking the share for education and science to $2.4 \%$ of GDP in 2013 .

Considering that state allocation amounts to $23 \%$ of the public HEI budget on average, HEIs generally cover capital expenditures and salaries from tuition fees. The budget of private HEIs is primarily based on tuition fees and amounts to 94-100\%. According to the WB Report 2013, the tuition level in Armenia is considered relatively high if measured against the GDP and compared with lower-middle income countries on the OECD list. It is calculated at 7-37 \% of GDP per capita PPP, whereas the maximum is $14 \%$ of GDP per capita PPP in the USA (OECD, Education at a Glance, 2012). Despite the steady increase in HEI gross enrolment from $19.6 \%$ in 2001 to $28.6 \%$ in 2008 , which compares well with the countries at a similar economic level in the ECA region (WB report 2013), equity of access is still a challenge.

\section{HE Landscape in Armenia: Current State of Affairs}

The reform of Armenian HE was initiated bottom-up in the early 1990s by leading scholars and top management at some leading universities. The first steps taken through pilot projects were the introduction of a two-tier degree structure, changes to curricula, and student assessment systems. In some cases, the changes were supported by international projects such as Tempus, Open Society Institute Assistance Foundation Armenia, the World Bank and the United States Departments of State and Education. However, ambiguity with regard to what should be done in what sequence, as well as how and why, resulted from a lack of clear vision for educational reforms (Zelvys 2004) and insufficient administrative capacity for change management, coupled with a lack of MoES guidance. In fact, the trend was predominant reliance on international consultants instead of building the capacities of local change owners. This, according to Fullan and Scott (2009), may have made things worse instead of better as the use of external consultants was not cost-effective and has caused overreliance on external support at the expense of developing inner capacity (Karakhanyan et al. 2011).

Further, the newly introduced approaches raised the issue of legitimacy; this was caused by lack of inquiry into the context in which the diffused 
policy was planted (Karakhanyan et al. 2011). One example is the revision of the approach to governance, which authorises public HEIs to be governed by a Governing Board (GB) with equal representation by stakeholders, state employees, renowned individuals, faculty members and students. While democratic in nature, an absent preparatory phase enabling the meaningful participation of such key stakeholders combined with negligence of contextualisation later resulted in decision-making manipulation.

Another trend was the unprecedented decline in the status and prestige of scholars and researchers conditioned by decades of low payment, overload, insufficient and inadequate resources for teaching and research, and demoralising management. The once highly prestigious profession lost its attraction among youth, which resulted in an aging faculty and therefore non-relevant methods and content delivery. One of the consequences of this trend is a tendency for highly qualified staff to leave academia for more lucrative positions so that vacancies are filled by less qualified individuals.

\section{BOLOGNA REFORMS}

In the 2000s, geared towards the establishment of an independent country and a democratic society, the Armenian government began to reconsider the whole architecture of the HE system. In 2003, the MoES developed the Strategy of HE Reforms, which led Armenia to join the Bologna Process in 2005. The MoES took the initiatives at the major policy making level, while giving HEIs some autonomy to make institutional and programme level changes. In May 2005 (Bergen Communiqué), the Development Strategy of Education for 2008-2015 was adopted and put into practice. The document was revised and reinforced through adoption of the Law on the Republic of Armenia Education Development Strategy on June 23, 2011. The main objectives were reflected in the State Program for Education Development 2011-2015, which sets key objectives and strategic directions for $\mathrm{HE}$ revolving around widening access to $\mathrm{HE}$, a national qualifications framework, enhancement of quality assurance, revising funding mechanisms, recognition and comparability of degrees, student mobility, strengthening the ties between HE and the labour market and ensuring effective governance and financial management of HEIs.

Drawing on the Strategy, the shift to a two-tier degree system (MoES decree, 2004) has been completed and almost $100 \%$ of students below 
the doctoral level are enrolled in two-cycle programmes. All HEIs issue Diploma Supplements and implement the European Credit Transfer and Accumulation System (ECTS) as of 2008, although with some difficulties. However, the move towards a two-tier degree has proved to have insufficient legitimacy for many professional sectors across the system (e.g. medicine) and required a necessary revision in 2015-2016 to align with market needs.

A new actor in the HE sector appeared as a direct result of joining the Bologna Declaration. A buffer body, the National Center for Professional Education Quality Assurance (ANQA), was established in 2008 as a new governmental tool to hold all HEIs accountable for their operations and outcomes. ANQA policies and procedures are aligned with the European Standards for Quality Assurance in the European HE Area (ESGs) of the European Network of Quality Assurance (ENQA) as well as the Guidelines of Good Practices (GGP) of the International Network for Quality Assurance Agencies in HE (INQAAHE). At HEI level, with major support from ANQA, internal quality assurance systems have been put in place and HEIs have completed the first round of institutional selfassessments. This is a move towards programme level self-assessment.

In 2011, the Armenian government adopted the National Education Qualifications Framework of the Republic of Armenia (ANQF) consisting of eight levels, and the responsibilities for the operation and maintenance of the ANQF are within the jurisdiction of the MoES. Currently, the ANQF is under revision based on the first round of its implementation and pilot evalution.

Armenia is pursuing a strong internationalisation policy. Currently, it is a member of the United Nations, the Commonwealth of Independent States, the Council of Europe and more than 40 other international organisations including OSCE, the World Bank, the International Monetary Fund, WTO, WHO and UNESCO, to name but a few. Supported by international missions, the leading HEIs are geared towards internationalisation and have been revamping their approaches to governance, administration and overall programme delivery. Internationalisation is pursued through development and integration of such dimensions as:

- Integration of an international dimension into the teaching, learning and research functions of universities by developing and implementing respective policies and procedures

- Identification and development of new skills, attitudes and knowledge in students, faculty and staff to promote internationalisation 
- Promoting scholar and student exchange and technical cooperation of HEIs

- Development of ethos and culture that values and supports intercultural and international perspectives, initiatives and their quality assurance

Among the current priorities on the government agenda is the refinement of the ANQF to move to the next step of self-certification, its full implementation and respective recognition internationally. Also included are a move from academic standards to a learning outcome approach to programme development and delivery as well as a revision of funding mechanisms.

\section{Legal and Regulatory Developments}

At the legal framework level, Armenian HE is regulated by the Law on Education adopted in 1999 and the Law on Higher and Postgraduate Professional Education adopted in 2004. The two documents clearly state the vision of $\mathrm{HE}$, which is aimed at international recognition, competitiveness and full integration into the European Higher Education Area (EHEA). As for regulations related to the research dimension, a new Law on the National Academy of Sciences was adopted in 2011 to ensure an autonomous legal status for the NAS. This sort of division actually created a gulf between HE and research and thus deprives HEIs of the opportunity to strengthen research functions.

The Law on Education (1999) and the Law on HE (2004) define the overall governance framework for $\mathrm{HE}$ in detail, but with ambiguity in favour of government control (WB 2013). However, due to their status, some HEIs are also regulated by the Law on State Non-Commercial Organizations and the Law on State Governing Institutions (SGIs), both adopted in 2001. The latter was not specifically developed for HEIs and does not take into account governance, autonomy and academic freedom guaranteed in education laws, thus contributing even more controversy. Given the current legal framework, the governance model can be defined as semi-autonomous (WB 2013).

Recently, a new trend of transitioning to foundation status has been observed. A foundation is a not-for-profit independent legal entity that enjoys the following privileges (Hasan 2007): 
(i) It is an independent legal entity.

(ii) It has a mission (or charter or mandate) to serve defined public (or national and societal) interests in HE and research.

(iii) As a not-for-profit public interest legal entity, it has favourable tax treatment on its incomes, assets and trading activities undertaken in pursuit of its foundation goals.

(iv) It has the autonomy to raise funds and manage its assets in pursuit of the foundation goals, for which it receives favourable tax treatment (2007, p.7).

Throughout the last couple of years, six state HEIs have changed their legal status to foundation, each by individual MoES decree. Thus, public HEIs in Armenia are now legally differentiated between State NonCommercial Organizations (SNCOs) and foundations.

The same cannot be said for private and intergovernmental HEIs, since they are less restricted in their operations. Private HEIs, depending on their status, are regulated by the Law on Education, the Law on HE, the Law on Enterprises and Entrepreneurial Activity, the Law on Foundations, the Law on LLCs, the Law on Cooperatives and/or the Law on Joint Stock Company (JSCs). Intergovernmental HEIs are regulated by the Law on Education, the Law on HE and the respective legal frameworks of their counterparts in home or host countries. Table 3.2 summarises the types of Armenian HEIs by legal status as of 2015 .

\section{FUNDING}

Diversification also affected the funding of HEIs. Public HEIs, which were previously run $100 \%$ on the state budget, now have legal authorisation to charge tuition fees. This has been the case since 1999. By the late 2000s, the average proportion of HEI budget share coming from the government was only $20 \%$, with the rest coming predominantly from student fees. Paradoxically, "public" HEIs in Armenia actually receive very little state contribution (WB 2013). New funding mechanisms include competitive innovation funds with a target to promote HEI competitiveness. Funding mechanisms are currently under revision with a diversification goal in mind. 


\section{New Admissions Policy}

The next major change was the revision of admissions policy, which moved from exams given by individual HEIs to a Centralised Admission Exam (CAE), which is both a school final and a university entrance examination. From 2005 to 2012, only state HEIs utilised a centralised admission exam process, which is organised and administered by the MoES's State Admission Commission (SAC). In the academic year 2012-2013, private HEIs were also subject to CAE for the first time, which was a major blow to the private sector threatening a total closure of some institutions. Exceptions apply to some public HEIs that still reserved the right to conduct subject specific exams as supplementary to the CAE.

Admissions to foreign-affiliated institutions are governed by individual HEIs, although these schools may choose to use state exam scores in their admission decisions.

With the introduction of unified exams, the landscape has transformed significantly due to intensified competition among HEIs for students. As a result, weaker public and most private HEIs are now forced to revise their approaches. The choice is whether or not to merge or revise their missions and concentrate mostly on life-long learning or further education courses to become more competitive in the market.

\section{Classification and Ranking of HEIs}

With regard to the vertical stratification of HEIs, under the Soviet approach distinctions in quality were reflected in the privileged status of a university vs. an institute. Recently, the MoES has come up with new mechanisms to classify HEIs:

- Ranking Web of Universities, which provides rankings per country as well ${ }^{1}$

- National classification of HEIs and ranking of programmes, based on a pilot project conducted by the MoES to classify and then rank HEI programmes within each classification.

The same trend could be observed implicitly, through the reputational stratification of HEIs broadly discussed at the society level. Such a stratification mainly places public and intergovernmental HEIs on top as the most prestigious HEIs. Recently, to move forward on the international 
visibility agenda, highly prestigious universities have been invited to establish branch campuses in Armenia as exemplified by the MoES's invitation of Moscow State University. Despite a history of about 25 years, private HEIs have not been able to live up to the standards expected by society. The main indicator for the public at large is the quality of teaching staff, availability of resources and, most importantly, national and international recognition of awarded degrees.

Vertical stratification could also be described as promoted by national accreditation, which serves as an accountability tool for the government and a tool for financial allocation. According to the ANQA revised procedures (2015), regardless of HEI legal status, those that fail to obtain accreditation will be deprived of state funds and will have limits set on tuition fees to be charged. This will become effective as of 2018. Thus, the new stratification tool has the potential to substantially change the HE landscape.

\section{Organisational Intervelationships}

Last but not least, an aspect of diversity worth elaborating on is organisational interrelationships. Although not very significant in the context of the developing Armenian system, these alliances create synergies in teaching and learning, research and community outreach activities. Interrelationships in the context of Armenia are promoted in the following ways:

- Static-empowered by buffer bodies or international organisations;

- Dynamic - natural evolutions based on the needs of the HE system and society at large.

With regard to the static, in its quest to develop a quality culture, ANQA tirelessly invests in the capacity building of different stakeholders. Capacity building events and peer reviews organised by ANQA actually create a collaborative culture and establish a firm platform for a quality education dialogue.

SCS,${ }^{2}$ through its grants, promotes research projects that bring together faculty members from different HEIs and, in some cases, industries. The same applies to international projects like Tempus, Erasmus+ and Twinning, which actually bring together HEIs to collectively pursue project objectives. As a natural evolution to this process, for example, the International Association of Educationalists (IntAE) has been established to bring together professionals from Armenia, Georgia and Europe. 
The dynamic form of interrelationships revolves around the establishment of industry-university collaborative partnerships, merging HEIs and partnership agreements. A prominent example of an industry-university collaborative partnership is Synopsis, which is the Silicon to Software ${ }^{\mathrm{TM}}$ partner for innovative companies developing electronic products and software applications. Additionally, it offers courses in microelectronics at the bachelor and master levels and the degree is awarded with its collaborative partners which include such IT leaders as YSU, SEUA, and RAU (Slavonic). Most graduates of this partnership are then hired by Synopsis itself.

A recent trend of merging HEIs is gradually becoming apparent. Currently, this form of interrelationship has been registered only in the private sector with some HEIs merging to serve the same purposes. However, at the government level there are also plans to merge public HEIs to achieve economies of scale.

\section{Classification of HEIs 2014-2015}

The HE system in the 1990s was characterised by only 1 full university, 11 professionally oriented institutes and 1 conservatorium. The new Law on Education adopted in 1999, however, allowed for a diversity of HE providers to enter the market. Thus, as seen from Fig. 3.5, from 1999 to

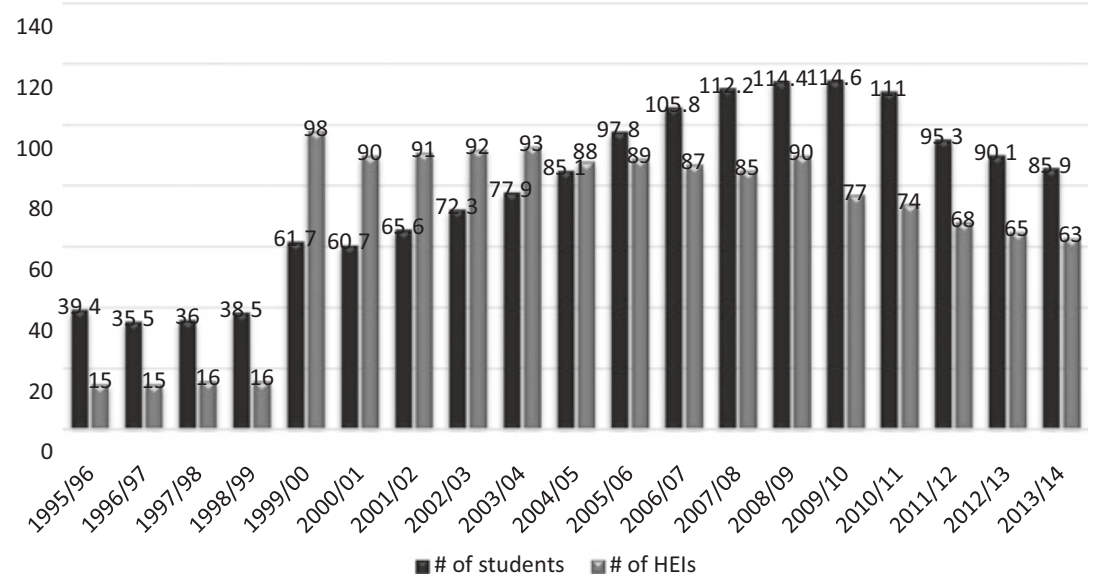

Fig. 3.5 Distribution of HEIs and number of students (Statistical Yearbook of Armenia: http://www.armstat.am/en/?nid=45\&year=2014) 
2008 a new type of HEI mushroomed. The initiators were mainly private entrepreneurs (e.g. Armenian diaspora to the USA, leading professionals in different fields like law and economics) and former leaders of public HEIs. Table 3.2 illustrates the diversity of HE providers as of 2015.

However, having set no boundaries on private initiatives, the system found itself with an abundance of private providers with quality levels that are still largely questioned. Starting in 2008 with persistent MoES efforts, the number of private HEIs was reduced from 98 in 1999 to 63 in 2013 and 57 in 2015 . The decline in the number of private HEIs was due to (1) toughening licensure criteria; (2) university mergers, which were applied in very few cases; and (3) imposing state unified entrance exams on private HEIs. The steady decline in enrolments is mainly explained by the decline in birth rates throughout the 1990s and beginning of the 2000s.

Currently, the HE system in Armenia consists of public, private, intergovernmental and transnational HEIs. At the national level, the executive authority to elaborate and implement government policies is the MoES, which tends to its mandate in cooperation with regional and municipal authorities. State HEIs operate under the responsibility of several ministries but most of them are under the supervision of the MoES. In total there are 26 state HEIs, of which 16 with 14 branches are under MoES jurisdiction; 4 HEIs were founded by intergovernmental agreements and partly funded by the MoES; 2 HEIs are under the Ministry of Defence, and one HEI is under each of the following ministries/bodies: Police, Ministry of Emergency Situations and Mother See of Holy Etchimiadzin. ${ }^{3}$ Of all the public HEIs, YSU has a special distinction as the only Armenian HEI with its own separate provision in the Law on Higher and Professional Education and a separate mention in the national budget (Table 3.3).

As demonstrated above, driven by the vision of internationalisation and the demands of the market economy, the HE landscape is gradually becoming diverse with three full universities qualified as comprehensive as well as specialised universities, institutes, academies, a conservatorium and research institutes to meet a diversity of needs.

Private HEIs are out of the scope of MoES jurisdiction to a considerable extent; however, the government imposes accountability mechanisms. Intergovernmental institutions are universities established on the basis of agreement between two countries, for example, the American University of Armenia, the Russian-Slavonic University of Armenia and the French University of Armenia. The trend of promoting transnational providers is escalating with the introduction of academic programmes within the 


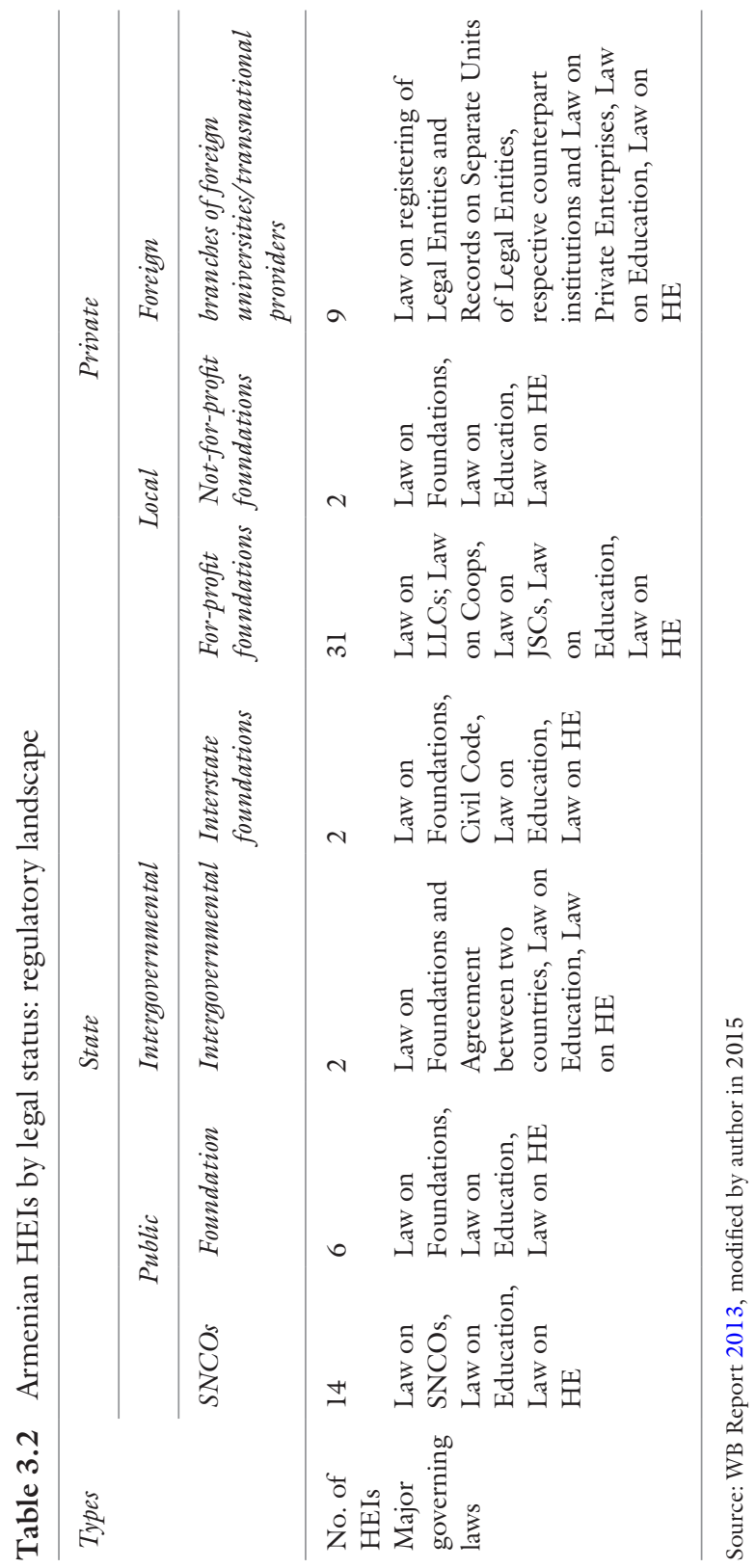




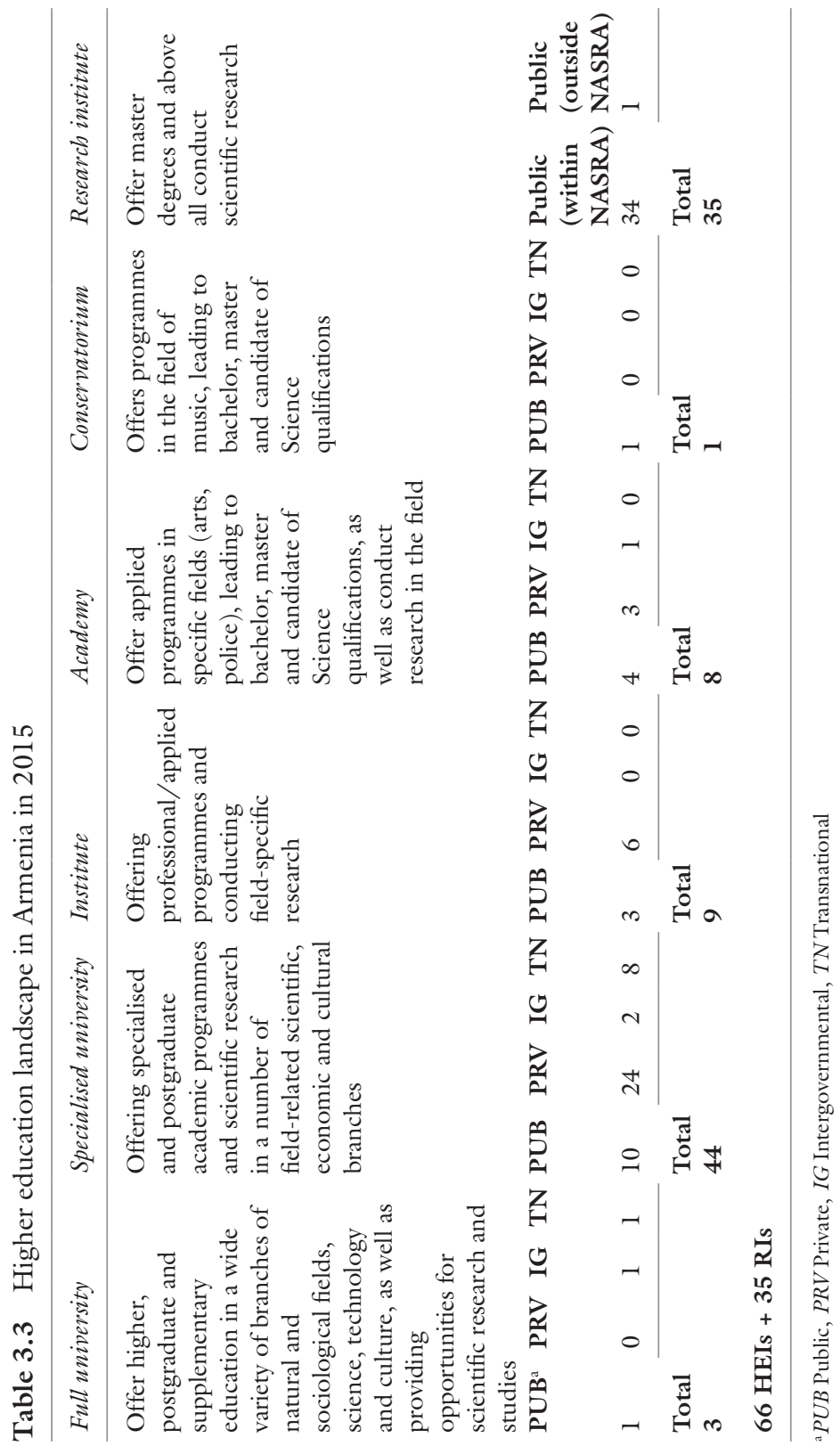


framework of existing HEIs (e.g. the Armenian University of Economics is hosting a programme from the United Kingdom). This also involves Armenia hosting worldwide leading university branches (e.g. Moscow State Lomonosov University), thereby bringing in a more diverse range of $\mathrm{HEl}$ providers.

All the HEIs are degree-awarding entities. All the private HEIs accredited by the MoES starting from 1999 under the old accreditation policy issue state-standard diplomas, which qualifies the graduates as the same level as those from public HEIs. However, the trust in degrees awarded by private HEIs is much lower in the labour market and society at large.

\section{Conclusions}

For the last century and a half, HE in Armenia has been driven by ideological and political factors and undergone major transformations resulting in system differentiation at horizontal and to some extent vertical level.

The first major transformation was compelled by the change to a Soviet and socialist ideology and industrialisation agenda when joining the USSR in 1923. Driven by the imperatives of the Soviet regime, there was a radical cessation of the ecclesiastic nature leading to the establishment of professionally oriented HEIs outside the church to meet the demands of society. As shown in Table 3.1, this resulted in the emergence of a full university as well as professionally oriented institutes and a conservatorium. The system was predominantly characterised by uniformity and was centrally planned and controlled by the government, with no opportunity for any other types of $\mathrm{HE}$ providers (e.g. private).

With the collapse of the Soviet system, HE in Armenia has undergone a major transformation at the horizontal level. The institutional landscape has expanded, not only in numbers but also in types, to include such HEIs as academies, professionally oriented universities, educational centres (foundations) and research institutes within National Academy of Sciences of the Republic of Armenia (NASRA); this is very different to the landscape in 1991 (Table 3.1 vs. 3.2). Further, the system evolved to host HEIs with diversity in terms of legal status: public, intergovernmental, transnational and private, which could further be differentiated between for-profit and not-for-profit providers. The contextual factors affecting the alteration of the institutional landscape are mainly related to the move to a market economy, national identity resurrection and the internationalisation agenda promoted by the government.

To achieve international visibility and respond to the changing trends in $\mathrm{HE}$, the transformations entailed the encouragement of private, inter- 
governmental and transnational providers. On the other hand, concerned with the rapidly increasing number of private providers with questionable quality, the government took steps to regulate the market newcomers by introducing accountability tools, for example by setting strict regulations and licensing and accreditation policies. This has led to the closure or merger of private and poorly performing public providers. Another example is the extension of centralised admission policy to private providers, which eventually compelled the latter to reorient their missions. Thus, the stimulators for horizontal differentiation could be summed up as driven by market demands for modernisation of qualifications and massification of $\mathrm{HE}$ as well as the government agenda for accountability, funding, internationalisation and recognition of qualifications.

Vertical differentiation is increasingly becoming a major concern for the government, HEIs and stakeholders. HEIs are becoming part of international and national rankings and classifications to enable measurement of achievements and comparative analysis of those achievements throughout time and across systems. Among the steps leading to vertical differentiation is the government attempt to invite highly ranked HEIs to establish branch campuses in Armenia (e.g. Moscow State University).

In sum, the transformations in the Armenian HE system have come in the form of differentiation at diverse levels. Considering that the drivers behind this differentiation are predominantly market requirements and political strategies at the government level leading to international visibility, the HE system is predominantly governed by a balance of national and global forces leading to convergence. Although it is still premature to speak about the level of convergence in actual implementation practices, HEIs in Armenia are becoming more convergent with those at the European level through such major tools as the NQF and its alignment with EQF, the independent quality assurance and accountability system, operationalisation of the credit transfer and accumulation system and a move towards two-tier education (bachelor and master).

\section{Notes}

1. http://www.webometrics.info/en/europe/armenia

2. State Committee of Science, established within the MoES in 2008 with a mandate to improve the science sector in Armenia. The body mainly promotes research by offering grants.

3. http://studyinarmenia.org/hea 


\section{REFERENCES}

CARIM. 2013. Refugees, Displaced Persons and Asylum Seekers in Armenia. RSCAS, CARIM East Project, European University Institute, Florence, Italy.

Chabe, A.M. 1971. Soviet Educational Policies: Their Development, Administration and Content. Association for Supervision and Curriculum Development, 525-531 in August, 2015. www.ascd.org/ASCD/pdf/journals/ ed_lead/el_197102_chabe.pdf

Hasan, A. 2007. Independent Legal Status and Universities as Foundations. Paris: UNESCO, International Institute for Educational Planning.

Karakhanyan, S., K. van Veen, and T. Bergen. 2011. Higher Education Policy Transfer and Diffusion: The Case of Armenia. Higher Education Policy 24: 53-83.

Khrushcheva, N., and A. Benvenuti. 2002. Lessons of Transition: The Cultural Contradictions and the Future of Russian Liberalization. New York: World Policy Institute.

Khudaverdyan, K.S. 1960. Cultural Changes in the Soviet Armenia During Prewar Five-Year-Time-Spans. Izvestiya Academii Nauk Armyanskoi SSR 3-17.

Kozma, T., and T. Polonyi. 2004. Understanding Education in European-East Frames of Interpretation and Comparison. International Journal of Education Development 24 (5): 467-477.

MoES. 2014. Education for All 2015 National Review Report: Armenia. Paris: UNESCO.

NAS. 2004. Science and Technology in Armenia: Toward a Knowledge-Based Economy. Washington, DC: National Academy of Sciences, The National Academies Press.

NSSRA. 2014. National Statistical Services of the Republic of Armenia. Yearbooks, March 2015. http://www.armstat.am/en/?nid $=45$ \&year $=2014$

Sarafian, K. 1930. History of Education in Armenia. California: La Verne Leader.

Suny, R. 1996. Armenia, Azerbaijan, and Georgia: Country Studies. Dane Publishing, Washington D. C.

Terzian, M.S. 2010. Curriculum Reform in Post-Soviet Armenia: Balancing Local and Global Contexts in Armenian Secondary Schools. Dissertations/107, Loyola University Chicago.

UNESCO. 1990. Higher Education in the USSR. Bucharest: CEPES. 2000. The EFA 2000 Assessment: Country report, Armenia. Paris.

UNHCR. 2004. UNHCR Statistical Yearbook. UNHCR Refugee Agency, Geneva, Switzerland.

van Vught, F. 2007. Diversity and Differentiation in Higher Education Systems. CHET Anniversary Conference, Cape Town.

WB. 2011. Public Expenditure Review. Washington, DC: World Bank. 
2013. Addressing Governance at the Center of Higher Education Reforms in Armenia. Washington, DC: World Bank.

Zelvys, R. 2004. Development of Education Policy in Lithuania During the Years of Transformations. International Journal of Educational Development 24 (5): $559-571$.

Susanna Karakhanyan is one of the founders of the National Center for Professional Education Quality Assurance in Armenia (ANQA) as well as the first President and current member of the (ANQA) Accreditation Commission. She is the current President of the International Network for Quality Assurance Agencies in Higher Education (INQAAHE). Dr. Karakhanyan holds an M.S.Ed. in Educational Administration from the University of Pennsylvania, USA, and Ph.D. in Social Sciences from the Radboud University Nijmegen, the Netherlands. Her research interests evolve around higher education policy development, diffusion and transfer, HE governance, administration and management in general and its quality assurance, in particular.

Open Access This chapter is distributed under the terms of the Creative Commons Attribution 4.0 International License (http://creativecommons.org/ licenses/by $/ 4.0 /$ ), which permits use, duplication, adaptation, distribution and reproduction in any medium or format, as long as you give appropriate credit to the original author(s) and the source, provide a link to the Creative Commons license and indicate if changes were made.

The images or other third party material in this chapter are included in the chapter's Creative Commons license, unless indicated otherwise in a credit line to the material. If material is not included in the chapter's Creative Commons license and your intended use is not permitted by statutory regulation or exceeds the permitted use, you will need to obtain permission directly from the copyright holder.

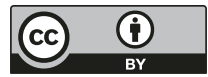

